\title{
Pet stores, aquarists and the internet trade as modes of introduction and spread of invasive macrophytes in South Africa
}

\author{
Grant D Martin* and Julie A Coetzee \\ Department of Zoology and Entomology, Rhodes University, PO Box 94, Grahamstown 6140, South Africa
}

\begin{abstract}
Submerged aquatic invasive plant species are increasingly being recognised as a major threat to South African water ways. Pet stores, aquarists and the internet-mediated trade were investigated as pathways for submerged invasive macrophyte introductions into South Africa. Online and manually distributed surveys were used to determine the extent of movement of invasive as well as indigenous submerged plant species in South Africa. Sixty-four stores and twenty-three aquarists were surveyed. Four areas of risk were identified in this study. Firstly, and most importantly, a variety of invasive and/or prohibited plants are sold by pet stores. Secondly, there is a lack of knowledge regarding identification as well as regulation of submerged species, which may then result in the unintentional trade of potentially invasive species. It seems that, in many cases, the pet stores are ignorant or misinformed of the potential dangers, rather than intentionally attempting to breach the legislation. Thirdly, aquarists own, trade and move plants in and around the country, which makes it very difficult to monitor which species are being moved around South Africa and to what extent. Finally, the internet is a pathway of potential concern, but it is difficult to quantify its contribution to the trade of invasive species in South Africa.
\end{abstract}

Keywords: Submerged macrophytes, introduction pathways, prohibited species, pet stores

\section{Introduction}

The introduction of harmful invasive aquatic plants is recognised as a major environmental threat to many aquatic ecosystems throughout the world, including South Africa. Numerous pathways of introduction are responsible for the distribution and spread of many of these species, such as the horticultural and aquarium trade, dumping of ballast water, unintentional movement of propagules (i.e., hitchhikers) and, increasingly, the internet trade. Historically, invasive species such as water hyacinth (Eichhornia crassipes (Martius) SolmsLaubach (Pontederiaceae)), flowering rush (Butomus umbellatus Linnaeus (Butomaceae)) and water poppy (Hydrocleys nymphoides (Willd.) Bucherau (Limnocharitaceae)) have been transported and traded due to their aesthetic and horticultural value (Cook, 1985). Other species have been traded for use in aquaria, such as fanwort (Cabomba caroliniana Grey (Cabombaceae)), dense water weed (Egeria densa Planch (Hydrocharitaceae)), Canadian water weed (Elodea canadensis Michaux (Hydrocharitaceae)), hydrilla (Hydrilla verticillata (L.f.) Royle (Hydrocharitaceae)) and tape grass (Vallisneria spiralis Linnaeus (Hydrocharitaceae)) (Cook, 1985). Despite the threat that these species pose, regulations to prevent unwanted species introductions from aquarium and ornamental sources currently lack authority worldwide (Padilla and Williams, 2004).

One third of the aquatic species on the International Union for the Conservation of Nature (IUCN) Invasive Species Specialist Group's list of the top 100 worst invasive species have spread via the aquarium trade or ornamental releases (Padilla and Williams, 2004). It is not surprising then that

\footnotetext{
* To whom all correspondence should be addressed.

욜 +2746 603-8702; fax: +2746 622-8959; e-mail: g03m0712@campus.ru.ac.za

Received 20 September 2010; accepted in revised form 30 May 2011.
}

the majority of submerged invasive plants in South Africa, the USA and New Zealand were introduced via the aquarium trade as ornamental and/or aquarium plants (Dehnen-Schmutz et al., 2007; Champion and Clayton, 2000; Heywood and Brunel, 2009; Rixon, 2010). For example, genetic analysis of hydrilla, recently found to be invading a water body in South Africa, revealed it to be identical to samples from Malaysia and Indonesia, the centre of the South African aquarium plant import trade line (Madeira et al., 2007). Regardless of their status as declared invaders, aquatic plants continue to be sold in many countries (Kay and Hoyle, 2001).

A growing aid to introductory pathways is the escalating use of internet and e-commerce, which has to a large extent been overlooked by researchers and policy makers alike (Derraik and Phillips, 2010). There are numerous listings of online nursery catalogues that contain many invasive aquatic or wetland plants (Kay and Hoyle, 2001). The invasive seaweed Caulerpa taxifolia (Vahl) C. Agardh (Caulerpales) has had dramatic ecological and economic consequences worldwide (Padilla and Williams, 2004).This species is readily available for purchase over the internet, and most, if not all, invasions of C. taxifolia worldwide can be traced back to aquaria releases or escapes (Padilla and Williams, 2004; Stam and Olsen, 2006). An e-commerce search conducted in California for species of Caulerpa was able to purchase the species from 30 internet retailers and 60 internet sites from all over the USA and Great Britain (Walters et al., 2006). The aquarium trade appears to be the main driver behind the increasing risks to aquatic ecosystems associated with the internet trade (Derraik and Phillips, 2010).

While most attention has been paid to the role of the international trade in species introductions, both deliberately introduced and passenger species (Dehnen-Schmutz et al., 2007), it is equally important to determine the rate of repeated local introductions of invasive species, not only through local outlets, but also through the general public discarding unwanted material (Kay and Hoyle, 2001; Duggan, 2010). There is a 


\begin{tabular}{|c|c|c|c|c|c|}
\hline \multicolumn{6}{|c|}{$\begin{array}{l}\text { Table } 1 \\
\begin{array}{c}\text { Plants currently categorised as declared weeds or those that pose a threat to South African water ways, } \\
\text { their conservation status and their current establishment status in South Africa }\end{array}\end{array}$} \\
\hline Family & Species & $\begin{array}{l}\text { Common } \\
\text { name }\end{array}$ & $\begin{array}{l}\text { Natural } \\
\text { distribution }\end{array}$ & Legal status & $\begin{array}{l}\text { Current status in } \\
\text { South Africa }\end{array}$ \\
\hline Haloragaceae & $\begin{array}{l}\text { Myriophyllum } \\
\text { spicatum L. }\end{array}$ & $\begin{array}{l}\text { Spiked } \\
\text { water- } \\
\text { milfoil }\end{array}$ & Eurasia & $\begin{array}{l}\text { Declared Weed: Category 1: (CARA } \\
(\text { Act No. } 43 \text { of 1983)1) } \\
\text { Importation prohibited (APA (Act } 36 \text { of } \\
\text { 1983) })^{2} \text { ) }\end{array}$ & Established \\
\hline Hydrocharitaceae & $\begin{array}{l}\text { Egeria densa } \\
\text { Planch. }\end{array}$ & $\begin{array}{l}\text { Dense } \\
\text { water } \\
\text { weed }\end{array}$ & Brazil & $\begin{array}{l}\text { Declared Weed: Category } 1 \text { (CARA } \\
\left.(\text { Act No. } 43 \text { of } 1983)^{1}\right) \text {. } \\
\text { Importation prohibited (APA (Act No. } 36 \\
\text { of } 1983)^{2} \text { ) }\end{array}$ & Established \\
\hline Hydrocharit & $\begin{array}{l}\text { Hydrilla verticil- } \\
\text { lata (Linnaeus } \\
\text { fill) }\end{array}$ & Hydrilla & $\begin{array}{l}\text { Australia, Asia, } \\
\text { Central Africa }\end{array}$ & $\begin{array}{l}\text { Proposed Category } 1 \text { (prohibited) invader } \\
\text { under revised CARA and draft NEMBA } \\
\text { regulations } \text { s. }^{3} \text {. } \\
\text { Importation prohibited (APA (Act No. } 36 \\
\text { of 1983)) }\end{array}$ & $\begin{array}{l}\text { Established } \\
\text { (one location) }\end{array}$ \\
\hline Hydrocharitaceae & $\begin{array}{l}\text { Elodea canaden- } \\
\text { sis Michaux }\end{array}$ & $\begin{array}{l}\text { Canadian } \\
\text { water } \\
\text { weed }\end{array}$ & North America & $\begin{array}{l}\text { Declared Weed: Category } 1 \text { (CARA } \\
(\text { Act No. } 43 \text { of } 1983)^{1} \text { ) } \\
\text { Importation prohibited (APA (Act No. } 36 \\
\text { of } 1983)^{2} \text { ) }\end{array}$ & Established \\
\hline Cabombaceae & $\begin{array}{l}\text { Cabomba caro- } \\
\text { liniana Grey }\end{array}$ & $\begin{array}{l}\text { Cabomba, } \\
\text { fanwort }\end{array}$ & $\begin{array}{l}\text { Native to } \\
\text { temperate } \\
\text { and subtropi- } \\
\text { cal America } \\
\text { (Ørgard, 1991) }\end{array}$ & $\begin{array}{l}\text { Proposed Category } 1 \text { (prohibited) invader } \\
\text { under revised CARA and draft NEMBA } \\
\text { regulations } \\
\text { Importation prohibited (APA (Act No. } 36 \\
\text { of } 1983)^{2} \text { ) }\end{array}$ & $\begin{array}{l}\text { Cultivated, not } \\
\text { yet established }\end{array}$ \\
\hline Cabombaceae & $\begin{array}{l}\text { Cabomba fru- } \\
\text { cata Schult. }\end{array}$ & $\begin{array}{l}\text { Red } \\
\text { cabomba }\end{array}$ & $\begin{array}{l}\text { South America } \\
\text { (Ørgard, 1991) }\end{array}$ & $\begin{array}{l}\text { Importation prohibited (APA (Act No. } 36 \\
\text { of 1983) }\end{array}$ & $\begin{array}{l}\text { Cultivated, not } \\
\text { yet established }\end{array}$ \\
\hline Alismataceae & $\begin{array}{l}\text { Echinodorus } \\
\text { cordifolius (L.) } \\
\text { Griseb }\end{array}$ & $\begin{array}{l}\text { Spade-leaf } \\
\text { sword }\end{array}$ & $\begin{array}{l}\text { Wetlands of } \\
\text { Mexico and } \\
\text { North America }\end{array}$ & $\begin{array}{l}\text { No legislation } \\
\text { Potentially invasive (Henderson and } \\
\text { Cilliers, 2002) Importation prohibited } \\
\left(\text { APA }(\text { Act No. } 36 \text { of } 1983)^{2}\right)\end{array}$ & $\begin{array}{l}\text { Established } \\
\text { (one location) } \\
\text { (D. Bellstedt, } \\
\text { pers. comm.) }\end{array}$ \\
\hline
\end{tabular}

1. Conservation of Agricultural Resources Act (CARA), 1983 (Act No. 43 of 1983 amended 2001).

2. Agricultural Pests Act, 1983 (Act No. 36 of 1983).

3. National Environmental Management: Biodiversity Act (Act No. 10 of 2004) (NEMBA). The draft NEMBA regulations were published in Government Gazette 32090 on 3 April 2009.

positive relationship between the number of propagules of a species released into systems and the chance of that species being able to establish (Cohen et al., 2007). In South Africa there are approximately 160 pet and aquarium traders registered with the South African Pet Traders Association (SAPTA) (SAPTA, 2008), but there are also numerous unlisted vendors and traders. Both the general public and plant dealers often misidentify and/or do not know the ecological repercussions of the species they are dealing with. The lack of knowledge regarding invasive species results in less care given to the overflow of ponds or the disposal of plants, which are often discarded into ponds, ditches, streams and rivers (Duggan, 2010). For example, water hyacinth escaped from an overflowing garden pond and established in the Nahoon River, Eastern Cape Province, South Africa (Hill, 2008).

Invasive submerged plants, possibly deriving from aquaria releases, pose a significant negative environmental and economic threat to South Africa, but thus far have been allowed to escape and spread with few or no control measures, as most attention has been paid to controlling more obvious floating aquatic plant invasions. Legislation exists in South Africa against the possession, importation, purchase, transportation and introduction of invasive species under the Agricultural Pests Act 1983 (Act No. 36 of 1983) and the Conservation of Agricultural Resources Act (CARA) 1983 (Act No. 43 of 1983, amended 2001). These regulations group species into 1 of 3 categories. Each category contains its own set of regulations and prohibitory measures; however, very few submerged aquatic plants are categorised as declared invaders under this Act (Table 1) (Henderson, 2001). Subsequently, the CARA regulations on invasive species were revised and aligned with the draft regulations on invasive species under the National Environmental Management: Biodiversity Act (Act No. 10 of 2004) (NEMBA). However, delays in the promulgation of these regulations mean that no enforcement has been possible. There is also a list of prohibited species that may not be imported or propagated in South Africa under the Agricultural Pests Act (No. 36 of 1983), which has recently been amended by the South African Department of Agriculture, Forestry and Fisheries (previously Department of Agriculture) and the Directorate of Plant Health, yet this does not appear to be aligned with the NEMBA or CARA regulations.

To date, insufficient research has been has been conducted on the introduction and movement of aquatic plants, particularly submerged aquatic plants, in South Africa, and on their potential to establish and spread. Aquatic plants are bought and traded through various organisations and private companies throughout South Africa, and often these plants are incorrectly labelled and/or unidentified. Therefore, the aims of this study were to investigate:

- The role that pet stores and aquarists play in the introduction, movement and trade of aquatic plants around South Africa 
- The extent to which invasive aquatic plant species are imported and traded in South Africa

- Which aquatic plant species are already in South African pet stores and are being traded to the general public

- The knowledge of pet store owners and aquarists with regard to which species they deal with, as well as the associated legislation

- The potential contribution of the internet trade to the introduction and movement of harmful and invasive species into South Africa

\section{Methods}

Two online surveys were conducted to determine if pet stores and aquarists are possible vectors of submerged aquatic plant invasions in South Africa. This was achieved by creating 2 separate online surveys (Appendix 1). Pet stores were also investigated for the sale of prohibited plant species. Pet store and aquarist surveys were analysed separately.

\section{Survey development for pet stores and aquarists}

The survey software, SurveyMonkey (SurveyMonkey, 2009), was used to create simple, anonymous, easy-to-use, online questionnaires. The survey presented pet store owners and aquarists with 10 questions regarding their knowledge of plants in which they traded (Appendix 1).

\section{Selection of test species}

Only 12 plant species were included in the survey. A comprehensive list of all blacklisted and invasive plants, under the Conservation of Agricultural Resources Act (CARA), 1983 (ACT No. 43 of 1983, amended 2001) and the list of species prohibited for importation or propagation under the Agricultural Pests Act, 1983 (Act No. 36 of 1983) would have proved too cumbersome and time consuming for respondents. The 12 test species were selected for the following reasons:

- Common aquarium, established out of cultivation in South Africa, non-native harmful species: Canadian water weed, dense water weed, spiked water-milfoil (Myriophyllum spicatum Linnaeus (Haloragaceae)), hydrilla and spade-leaf sword are regarded as dangerous invaders to South Africa and have established in South African water ways (Henderson and Cilliers, 2002; Coetzee et al., 2009; Bellstedt, 2009) (Table 1).

- Common aquarium, potential non-native harmful species: Red cabomba is often confused with fanwort, and both are potential invader species in South African water ways (Coetzee et al., 2009; Henderson and Cilliers, 2002) (Table 1).

- Common aquarium species: Tape grass (Vallisneria spiralis L. (Hydrocharitaceae)), a cosmopolitan species, and hornwort (Ceratophyllum demersum L. var. demersum (Ceratophyllaceae)), which is indigenous to the Old World, both are common aquarium plants but are not classified as invasive.

- Indigenous alternative species: South African oxygen weed Lagarosiphon major (Ridley) Moss, Lagarosiphon muscoides Harvey. (Hydrocharitaceae) and curly pond weed (Potamogeton crispus Linnaeus (Potamogetonaceae)) as they are common species indigenous to South Africa that could easily be utilised as alternatives to invasive aquarium species (Cook, 2004).
All common names, alternate names and scientific names were provided on the questionnaires. No pictures were provided.

Three aquatic plant dealers/pet store owners and three members of an aquatic plant society completed an initial version of the surveys to assess the difficulty of the survey. In response to their comments, a few minor changes to the questions were made. The complete questionnaires were then uploaded to the internet for completion by respondents.

The survey was advertised in the SAPTA newsletter (August, 2009), 20000 copies of which were produced and distributed nationally. All 160 members of SAPTA were sent an e-mail message from the SAPTA secretary requesting their co-operation in the survey. The survey was advertised and distributed on popular aquarist blog pages, internet sites, by word-of-mouth and via e-mails within the aquarist communities. The survey was advertised for 4 months, and 23 surveys were completed by aquarists. The survey focused more on informed aquarists that frequent aquatic blogs and aquatic plant internet sites.

The survey was also taken to approximately 125 pet stores trading in aquatic plants in South Africa. Locations visited included Johannesburg, Pretoria, Port Elizabeth, East London, Grahamstown, King Williams Town, Jeffrey's Bay, Bethlehem, Bloemfontein, Cape Town, George, Knysna, Riebeeck Kasteel, Stellenbosch, Somerset West, Durban, Pietermaritzburg, Ballito, Hillcrest, Pinetown and Richards Bay. Twenty stores failed to complete the survey, 35 refused to complete the survey, 5 pet store owners requested to return the survey via the postal service but the survey was never received, and 1 store prohibited entry onto to their premises. A total of 64 surveys were completed by pet store owners. Data from questionnaires were collected and tested for correlations between key questions.

An internet search for the sale and distribution of prohibited and/or invasive aquatic plants in South Africa was also conducted. Search engines such as Google and Yahoo were initially used, but business websites were also examined, as were forums on aquatic plant enthusiasts, clubs and societies. Common names and choice key words were utilised for the searches (e.g. cabomba, oxygen plant or aquarium plant). Once a list of aquarium or water garden plants for sale was located, the list was examined for invasive and harmful species. A vendor was classified as a business or person selling plants for a monetary income; a hobbyist discarding unwanted or surplus plants would not be classified as a vendor. A second determinant of a vendor was that they had to post or courier live plants to the customer. The search was conducted to give a broad perspective of the extent of the online aquatic plant trade in South Africa. The plants were not purchased to determine if they were correctly identified by vendors, nor ordered to see if they would be delivered via the postal service, as this was not the aim of the search. The search did provide insight into the trade in South Africa thus bringing attention to the inherent and documented dangers of the online live organism trade.

\section{Results}

\section{Pet stores}

Sixty-four pet stores responded to the questionnaires. Of the pet store respondents, $34 \%$ could not identify a single test plant species presented on the survey. Less than $15 \%$ of respondents were able to identify spiked water milfoil, hydrilla and 


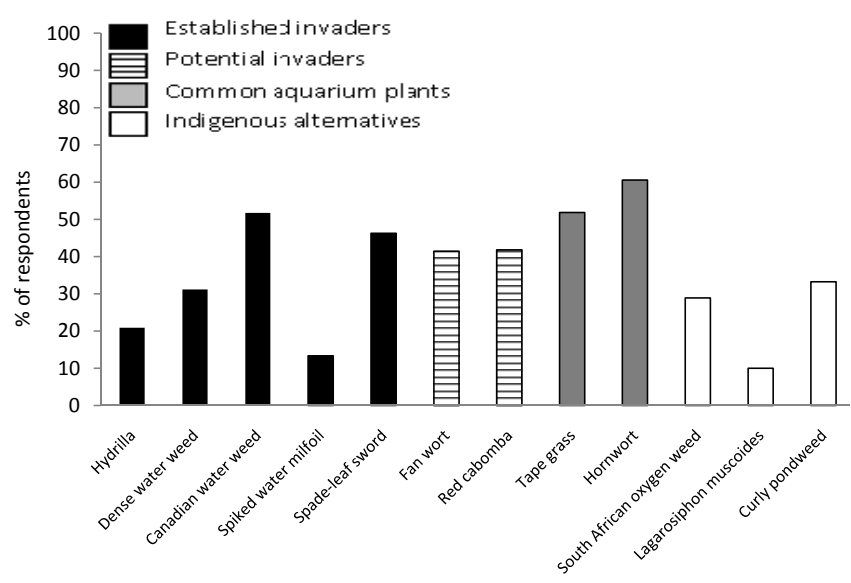

Figure 1

The percentage of pet store respondents able to successfully identify the test species provided

L. muscoides (Fig. 1). Tape grass (61\%), Canadian water weed (52\%), spade-leaf sword (46\%) and hornwort (61\%) proved to be the most recognisable species to pet store respondents; $41 \%$ could identify both red cabomba and fanwort (Fig. 1). There was a strong correlation between the ability of a pet store respondent to identify specific plant species and whether they had the opportunity to acquire the plant species $\left(R^{2}=0.97\right.$, $P<0.05)$.

Even though the percentage of pet store owners able to identify the test species was low, $50 \%$ of pet store respondents had the opportunity to acquire many of the test species (Fig. 2a). The least available species included hydrilla (12\%), L. muscoides $(12 \%)$ and spiked water-milfoil $(15 \%)$, whereas tape grass $(82 \%)$ and spade-leaf sword (74\%) were the most common test species available to pet stores (Fig. 2a). There was a strong correlation between what species the pet store respondents were able to acquire and what species they had in stock for sale $\left(R^{2}=0.92, P<0.05\right)$. Test species that pet stores had offered for sale at some stage included tape grass $(71 \%)$, spade-leaf sword (68\%), oxygen weed (47\%) and hornwort $(49 \%)$, whereas hydrilla (3\%), spiked water milfoil (7\%), oxygen weed (21\%) and L. muscoides $(17 \%)$ were stocked the least. The prohibited species, Canadian water weed $(38 \%)$, fanwort $(43 \%)$, red cabomba (38\%) and dense water weed (48\%), were also stocked regularly by the pet stores (Fig. 2b).

Ninety-four percent of pet stores received their test species from suppliers rather than growing their own plants, while mail order or self-collection were infrequent modes of plant acquisition. A few respondents described how they collected dense oxygen weed, hornwort, Kariba weed (Salvinia molesta D.S. Mitchell (Salviniaceae)) and water hyacinth from water bodies in their area to sell in their stores. With regard to selection of test species, $84 \%$ of pet stores selected their stock based on availability, followed by demand $(25 \%)$ and aesthetic value (18\%). Only a few stores had stock imported from abroad, including Malaysia, the Netherlands and Singapore.

The majority of pet store owners were not aware of the CARA (63\%) or NEMBA (72\%) regulations $(65 \%)$. Respondents who had knowledge of the regulations did not personally agree with the regulations, with the common explanation that they were not consulted and/or informed of the regulations.

Pet stores' stock was investigated during the time of the survey; however, the species were not purchased to confirm

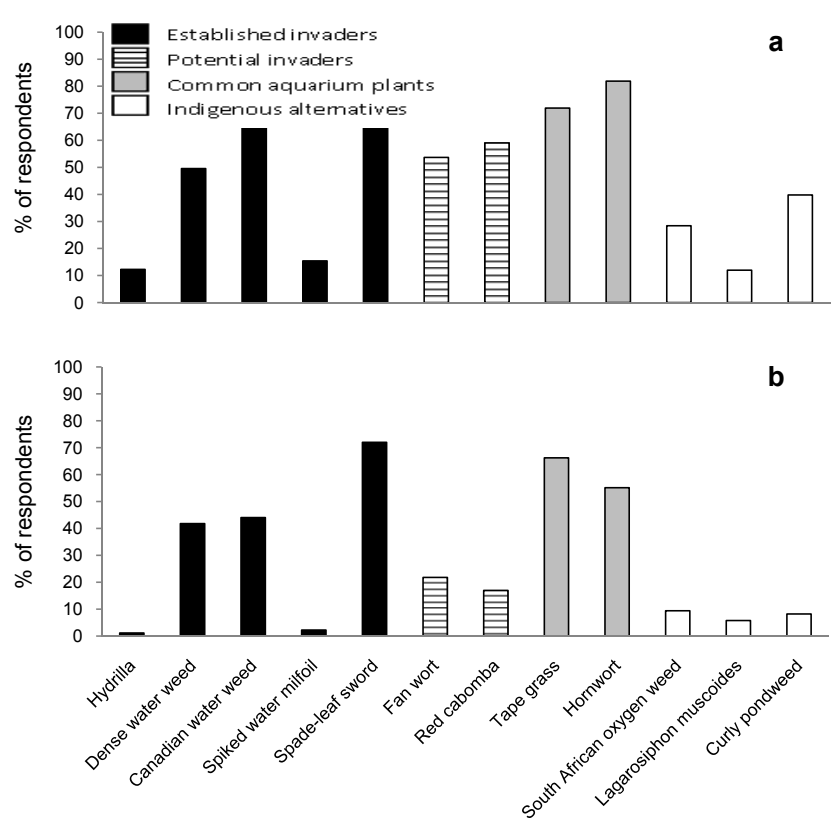

Figure 2

a The percentage of pet store respondents able to acquire the test species

b Percentage of respondents who stocked the test species

their identification. Prohibited species as well as species not permitted for import into South Africa available at pet stores included: red water fern (Azolla filiculoides Lamarck (Azollaceae)), water lettuce (Pistia stratiotes Linnaeus (Araceae)), Kariba weed (Salvinia molesta D.S. Mitchell (Salviniaceae)), all prohibited under CARA, 2001; and Hygrophila sp. (Acanthaceae), Asian Ambulia (Limnophylla sessiliflora (Vahl) Blume (Plantaginaceae)), and Sagittaria (Sagittaria platyphylla (Engelm.) J.G. Sm (Alismataceae)), prohibited under the draft regulations on invasive species under the NEMBA (Act No. 10 of 2004). Furthermore, broadleaved Anubias (Anubias barteri Schott (Araceae)), dwarf Anubias (Anubias barteri var. nana (Engler) Crusio (Araceae)), water trumpet (Cryptocoryne sp. (Araceae)), Cryptocoryne wendtii de Wit (Araceae), water chestnut (Trapa natans L. (Lythraceae)) , melon sword Echinodorus Osiris (Alismataceae), Echinodorus sp. (Alismataceae), Ludwigia sp. (Onagraceae), Myriophyllum sp. (Haloragaceae), yellow waterlily (Nymphaea mexicana Zucc (Nymphaceae)), Rotala macrandra Koehne (Lythraceae), and Vallisneria sp. (Hydrocharitaceae) were also recorded, which are species that are prohibited for importation into or propagation in South Africa on the Department of Agriculture import permit (Pests Act, No. 36 of 1983), yet do not appear on any of the CARA or NEMBA regulations.

\section{Aquarist respondents}

Twenty-three aquarists responded to the questionnaire. In contrast to the pet store surveys, over $50 \%$ of aquarist respondents could successfully identify all of the species on the test list, with tape grass $(91.3 \%)$ and hornwort $(91.3 \%)$ the most frequently positively identified. Lagarosiphon muscoides and curly pondweed species proved to be the most difficult test species for aquarist respondents to identify (Fig. 3).

All of the aquarist respondents had the opportunity to acquire the majority of the test species. Tape grass (87\%), dense 
water weed (70\%), Canadian water weed (70\%), fanwort (79\%), red cabomba (74\%), hornwort (96\%) and spade-leaf sword (78\%) were the most prevalent species available to aquarists (Fig. 4a). Hydrilla (39\%), oxygen weed (34\%) and L. muscoides $(30 \%)$ were the least abundant species available to aquarists (Fig. 4a). There was a strong correlation between the percentage of aquarists who had the opportunity to acquire the test species and the percentage of aquarists who had at some stage kept the test species in their aquarium or planted tank $\left(R^{2}=0.95\right.$, $P<0.05)$, with $L$. muscoides (4\%) and curly pond weed (21\%) being the least kept species. Tape grass (74\%), dense water weed (70\%), and Canadian water weed (56\%), fanwort (65\%) hornwort (91\%) and spade leaf sword (65\%) were extensively kept by aquarists (Fig. 4b). Low numbers of the test species were recorded to be traded or passed between colleagues. Fewer than $30 \%$ of aquarists had ever traded or passed on any of the test species; however, some of the test species were still traded, with tape grass (26\%), dense water weed (30\%) and fanwort (30\%) being the most common (Fig. 4c). There was also a strong correlation between the percentage of test species that had at some stage been kept in the aquarist's aquarium or planted with the test species that had been traded or passed on between aquarists $\left(R^{2}=0.82, P<0.05\right)$.

The aquarists surveyed appeared to have good knowledge regarding the threat that prohibited species pose to South African waterways, indicating, in their opinion, that hydrilla $(65 \%)$, spiked water milfoil (65\%), dense oxygen weed (65\%) and fanwort (65\%) pose the most significant threat to South African waterways. However, they also regarded that spadeleaf sword (26\%), a potential invader, poses a lesser threat to South African waterways. It was also noted that no aquarist respondent had ever released any prohibited species into any waterways within the country.

In contrast to the pet store respondents, a high proportion of aquarists (66\%) were familiar with the CARA as well as the NEMBA regulations (65\%), and the majority of those respondents did not personally agree with the regulations $(87 \%)$. A variety of reasons were given for the apparent dissatisfaction by aquarists with the regulations. Common trends included: firstly, that the lack of information and research regarding aquatic plants species in South Africa has resulted in decisions being made without a suitable knowledge base; secondly, the persons taking the decisions or making recommendations about imports had no experience in aquatic plants; thirdly, suitably knowledgeable aquarists or pet shop owners, of which there are quite a number, were not consulted or were wilfully excluded from decision making; and, finally, a number of respondents raised the point that the guidelines have been amended from Hawaiian and Singapore guidelines which has led to the banning of the importation of some plants that may not actually be invasive in South Africa.

\section{Internet survey}

Over 40 invasive species to South Africa or species not permitted for import into South Africa were found to be sold online by South African online vendors. However, these species were restricted to only 8 online vendors. Aquarists trading species online for other plants, aquarium fish and sometimes money was more common but very difficult to quantify.

Of the 8 sites actively selling plants online, only a single site had a large variety of invasive and harmful species for sale. Most of the other sites were limited to a select few invasive or harmful species, namely: broadleaved Anubias (5),

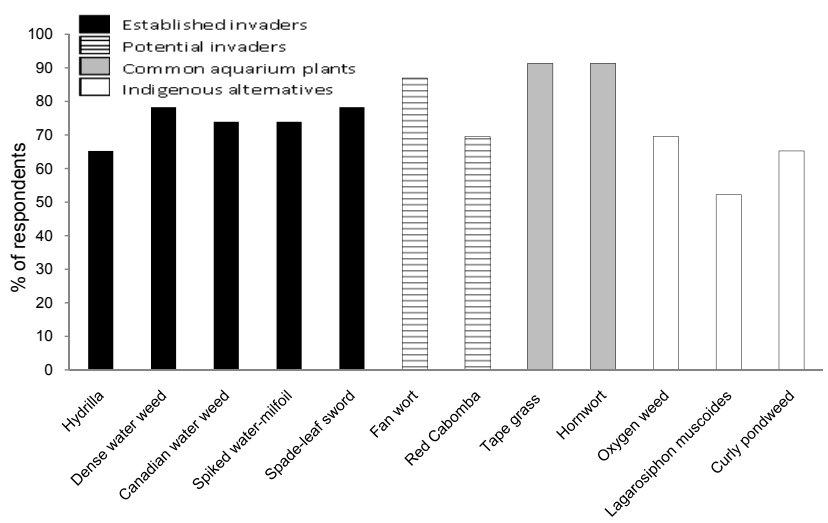

Figure 3

The percentage of aquarists able to successfully identify test species
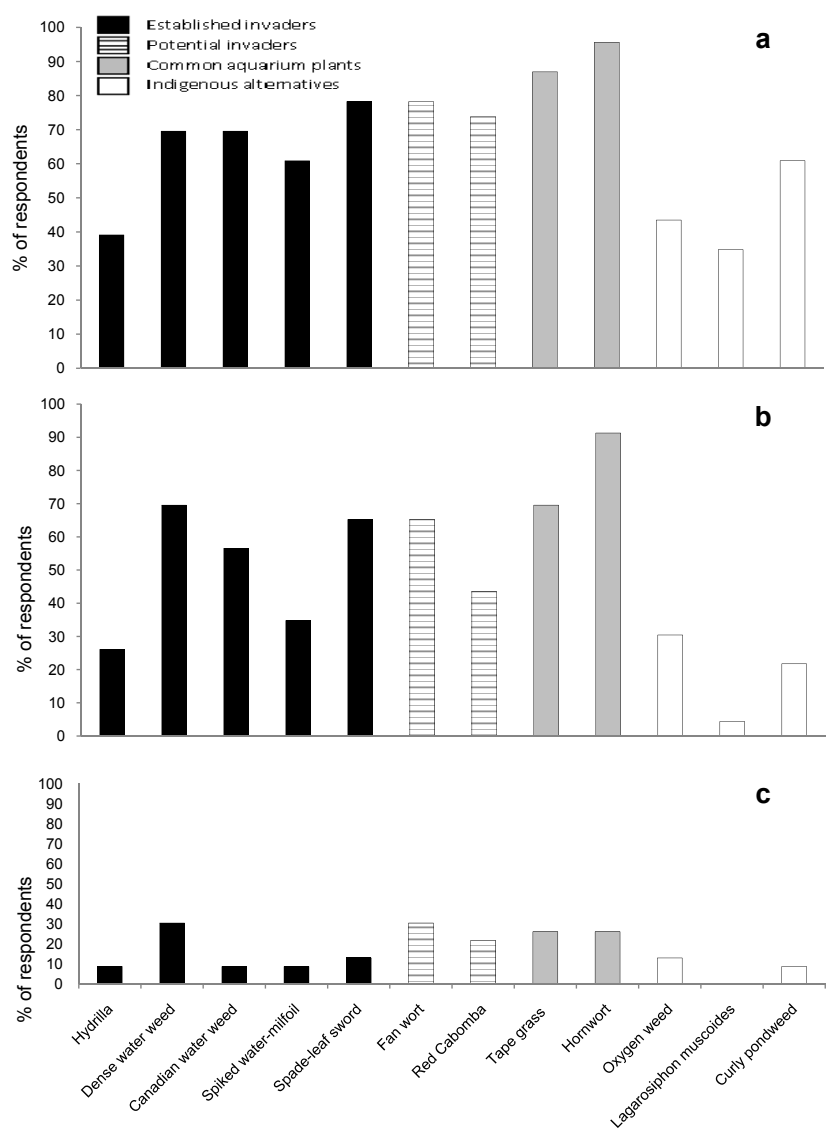

Figure 4

a The percentage of aquarists who had the opportunity to acquire test species

b Percentage of aquarists who had at some stage kept the test species in their aquarium or planted tank c Percentage of test species traded or passed on between aquarists

dense water weed (4), Cryptocoryne wendtii (3) red melon sword (Echinodorus bathii Muhlberg (Alismataceae)) (3) and dwarf hygrophila Hygrophila polysperma (Roxb.) Anders (Acanthaceae)) (3). Whereas Anubias congensis N.E. Brown (Araceae)), Anubias nana, fanwort, Cryptocoryne ciliate (Roxb.) Fisch. ex Wydler (Araceae), water hyacinth, Canadian water weed, pennywort (Hydrocotyle leucocephala Cham. \& Schlecht. (Apiaceae)), Ambulia (Limnophila sessiliflora 
(Vahl) Blume (Plantaginaceae)), spiked water-milfoil, water lettuce and Kariba weed were recorded for sale on only 2 South African internet sites.

\section{Discussion}

Intentional release from aquarium into the environment is one of the top 5 avenues for introduction of non-native invasive aquatic species, but has received relatively little attention from both scientists and policy makers (Padilla and Williams, 2004). This study shows that potentially invasive and prohibited plant species are being sold and traded by pet stores and aquarists in South Africa. Identifying and quantifying the impacts and threats posed by this trade is invaluable, as prevention of introductions usually proves more cost-effective than postintroduction eradication or control (Leung et al., 2002; Coetzee et al., 2009). The results of this study will likely have relevance for the non-native aquatic plant trade of other aquarium taxa in South Africa.

While the survey presents a sample of the potentially invasive and prohibited species in South Africa, it gives adequate representation of the variety and quantity of plants moving through pet stores, allowing for the opportunity to predict potential invasions before they arise. It also highlights the immediate need for the implementation and enforcement of the regulations to prevent the continued trade of invasive species to the general public. In the USA alone, the total cost of controlling just 3 escapees - purple loosestrife (Lythrum salicaria L. (Lythraceae)), spiked water milfoil, and water-chestnut exceeds US\$800 million per year (Pimentel et al., 2005). The current survey shows that in South African pet stores similar invasive and prohibited species are frequently sold, which could ultimately cost the country millions to control.

The introduction and establishment of non-native species in the natural environment via the aquarium trade relies on the likelihood that the more organisms that are sold to the general public, the greater the chances of escape, and, ultimately, the greater the chance of establishment (Cohen et al., 2007; Duggan, 2010). Quantification of the number of invasive plants that reach the consumer is essential. However, quantification of the risk posed by the trade in South Africa is very difficult because a proportion of pet trader respondents were unable to identify the majority of species being sold, let alone the invasive aquatic species. In a survey in the USA it was also shown that misidentification in the live organism trade is common and that consumers can never be sure which species they are receiving (Keller and Lodge, 2007). The test plants provided in this survey were chosen because they were deemed to be common aquarium species and should have been easier to identify than some of the other less frequently encountered aquarium species. Interestingly, the type of plants species being sold to the public by the pet stores predominantly relied on the availability of plants to the pet store and not on the actual species, thus highlighting the need for education among the general public, as well as pet store owners, on the risks associated with the species. This also highlights the fact that suppliers of aquatic plants should be targeted as the first step in control. If the distributors do not provide invasive species in the first place, prohibited and potentially troublesome plants will not end up in the pet stores.

The lack of knowledge regarding regulations by pet store owners results in the continued importation and trade of invasive species. The most recent example in South Africa is the occurrence of 600 ha of hydrilla in Pongolapoort Dam, which has been traced to Malaysian origins (Madeira et al., 2007). It seems that in many cases the culprits are ignorant or misinformed of the potential dangers, rather than intentionally attempting to breach the legislation. Additionally, the legislation itself proves confusing. For example, Anubias sp. have been in South Africa for the past 40 years and are quite common, yet have been included in the list of prohibited species that may not be imported or propagated in South Africa under the Agricultural Pests Act (No. 36 of 1983), in a category stating that they do not occur in the country and must never be allowed in (Stallard, 2010). Numerous other species found during this study are also on this list. This highlights the need for scientists, legislators and industry to have more input into decision making, which should not be conducted by one of these groups acting alone.

A challenge for enforcement is that, outside of the aquarium trade, numerous plants are moved through networks of aquarists who often stay in contact via the internet. Improved transport and packaging technology has made trade between countries and continents possible, making it very difficult for the enforcement of regulations. This study showed that aquarist respondents from this survey have a far greater knowledge than pet store owners, of both indigenous and invasive plant species, and were also far more informed about invasive plant regulations. As a result, it is likely that informed aquarists pose a lesser threat to biosecurity than pet stores as no aquarist respondent claimed to have ever considered releasing or actually released a plant species into waterways. However, these data were obtained from informed aquarist respondents who would have knowledge of best practice, and do not represent the casual aquarist who would have more chance of releasing or discarding unwanted live organisms into storm drains or local waterways, the occurrence of which has been documented in multiple examples worldwide (Fuller, 2003; Rixon et al., 2005; Duggan, 2010). However, pet stores have no control over whom they sell plants to, thus uninformed aquarists may still pose a significant threat to biosecurity.

Aquatic plants are known to be dispatched around the world by mail order. The internet only makes the task of finding and purchasing mail order plants easier (Champion and Clayton, 2000). In US markets, federal noxious weeds are extensively sold online (Maki and Galatowitsch, 2004). In South Africa, approximately 40 different prohibited or potentially troublesome macrophytes were sold online. This mode of introduction is cause for considerable concern as it is very difficult to control and monitor (Maki and Galatowitsch, 2004).

This study has clearly shown that the movement and trade of submerged invasive species in the aquarium and water garden community poses a substantial risk for introductions into the natural environment. Four areas of risk were identified in this study. Firstly, and most importantly, a variety of invasive and/or prohibited plants are sold by pet stores. Secondly, there is a lack of knowledge regarding identification as well as regulation of submerged species, which may then result in the unintentional trade of potentially invasive species. It seems that in many cases the pet stores are ignorant or misinformed of the potential dangers, rather than intentionally attempting to breach the legislation. Thirdly, aquarists own, trade and move plants in and around the country, which makes it very difficult to monitor which species are being moved around South Africa and to what extent. Finally, the internet is a pathway of potential concern, but it is difficult to quantify its contribution to the trade of invasive species in South Africa. This trade currently remains small but its development should be monitored. 
In conclusion, in order to mitigate the potential negative impacts of further aquatic plant invasions in South Africa, the pathways of aquarium plant movement need to be monitored and controlled with more rigour until the regulations and policies are developed, promulgated and agreed upon by the majority of vendors and aquarists involved. Once these regulations are in place, investment and effort has to be made in the education of pet store owners and aquarists regarding the dangers of invasive and harmful plants species.

\section{Acknowledgements}

We acknowledge the Working for Water Nurseries Partnership Programme of the Department of Water Affairs, the National Research Foundation's Thuthuka Programme and the Joint Research Council of Rhodes University for funding this study. Neil Stallard (SAPTA), Ryan Yates (Aquatic Plants South Africa (APSA)), Prof. Dirk Bellstedt, and Leslie Ter Morshuizen (Aquaculture Innovations) are acknowledged for assistance and comments on the questionnaires and drafts of this manuscript. Lesley Henderson (Agricultural Research Council - Plant Protection Research Institute Weed Division) is thanked for comments on legislation.

\section{References}

AGRICULTURAL PESTS ACT (1983) Act No. 36 of 983. Government Printers, Pretoria, South Africa.

BELLSTED DU (2009) Personal communication, 5 April 2009. Professor of Biochemistry. Department of Biochemistry, University of Stellenbosch. Private Bag X1, 7602, Matieland, South Africa.

CHAMPION PD and CLAYTON JS (2000) Border control for potential aquatic weeds - Stage 1 weed risk model. Science for Conservation 141. Department of Conservation, Wellington, New Zealand.

COETZEE JA, HILL MP and SCHLANGE D (2009) Potential spread of the invasive plant Hydrilla verticillata in South Africa based on anthropogenic spread and climate suitability. Biol. Invasions 11 801-812.

COHEN J, MIROTCHNICK N and LEUNG B (2007) Thousands introduced annually: the aquarium pathway for non-indigenous plants to the St. Lawrence Seaway. Front. Ecol. Environ. 5 528-532.

CONSERVATION OF AGRICULTURAL RESOURCES ACT (1983) (Act No. 43 of 1983). Government Gazette No. 429 (22166). Government Printers, Pretoria, South Africa.

COOK CDK (1985) Range extensions of aquatic vascular plant species. J. Aquat. Plant Manage. 23 1-6.

COOK CDK (2004) Aquatic and Wetland Plants of Southern Africa. Backhuys Publishers, Leiden. 140-148.

DEHNEN-SCHMUTZ K, TOUZA J, PERRINGS C and WILLIAMSON M (2007) A century of the ornamental plant trade and its impact on invasion success. Diversity Distrib. 13 527-534.

DERRAIK JGB and PHILLIPS S (2010) Online trade poses a threat to biosecurity in New Zealand. Biol. Invasions 12 1477-1480.

FULLER PL (2003) Freshwater aquatic vertebrate introductions in the United States: patterns and pathways. In: Ruiz GM and Carlton JT (eds.) Invasive Species: Vectors and Management Strategies. Island Press, Washington, D.C. 123-151.

HENDERSON L (2001) Alien Weeds and Invasive Plants. A Complete Guide to Declared Weeds and Invaders in South Africa. Plant
Protection Research Institute, Handbook No. 12. Plant Protection Research Institute, Pretoria, South Africa. 300 pp.

HENDERSON L and CILLIERS CJ (2002) Invasive Aquatic Plants. A guide to the identification of the most important and potentially dangerous invasive aquatic and wetland plants in South Africa. Agricultural Research Council, Pretoria. 88 pp.

HEYWOOD V and BRUNEL S (2009) Code of Conduct on Horticulture and Invasive Alien Plants. Convention on the Conservation of European Wildlife and Natural Habitats (Bern Convention). Nature and Environment No. 155. Council of Europe Publishing. $74 \mathrm{pp}$.

HILL MP (2008) Personal communication, 25 October 2009. Professor and Head of Entomology, Rhodes University. P.O. Box 94 Grahamstown 6140, South Africa.

HISCOCK P (2003) Encyclopaedia of Aquarium Plants. Interpret Publishing. New York. 10-11.

KAY SH and HOYLE ST (2001) Mail order, the Internet, and invasive aquatic weeds. Aquat. Plant Manage. 39 88-91.

KELLER RP and LODGE DM (2007) Species invasions from commerce in live aquatic organisms: problems and possible solutions. Bioscience 57 428-436.

LEUNG B, LODGE DM, FINNOFF D, SHOGREN JF, LEWIS MA and LAMBERTI G (2002) An ounce of prevention or a pound of cure: bio economic risk analysis of invasive species. Proc. Roy. Soc. B. Bio. 269 2407-2413.

MADEIRA PT, COETZEE JA, CENTER TD, WHITE EE and TIPPING PW (2007) The origin of Hydrilla verticillata recently discovered at a South African dam. Aquat. Bot. 87 176-180.

MAKI K and GALATOWITSCH S (2004) Movement of invasive aquatic plants into Minnesota through the horticultural trade. Biol. Conserv. 118 389-396.

NATIONAL ENVIRONMENTAL MANAGEMENT: BIODIVERSITY ACT (NEMBA) (2004) Act No. 10 of 2004. Government Gazette 32090, 3 April 2009. Government Printers, Pretoria, South Africa.

ØRGAARD M (1991) The genus Cabomba (Cabombaceae) - a taxonomic study. Nord. J. Bot. 11 179-203.

PADILLA DK and WILLIAMS SL (2004) Beyond ballast water: aquarium and ornamental trades as sources of invasive species in aquatic ecosystems. Front. Ecol. Environ. 2 131-138.

PIMENTEL D, ZUNIGA R and MORRISON D (2005) Update on the environmental and economic costs associated with alien-invasive species in the United States. Ecol. Econ. 52 273-288.

RIXON CAM, DUGGAN IC, BERGERON NMN, RICCIARDI A and MAC-ISAAC HJ (2005) Invasion risks posed by the aquarium trade and live fish markets to the Laurentian Great Lakes. Biodivers. Conserv. 14 1365-1381.

SAPTA (SOUTH AFRICAN PET TRADERS ASSOCIATION) (2008) URL. http://www.sapettraders.co.za/members.html (Accessed 4 November 2008).

STALLARD N (2010) Personal communication, 23 June 2010. Committee member for the Aquaculture Association of South Africa. Fish Designs, PO Box 41, Gingindlovu, 3800, South Africa.

STAM WT, OLSEN JL, ZALESKI SF, MURRAY SN, BROWN KR and WALTERS LJ (2006) A forensic and phylogenetic survey of Caulerpa species (Caulerpales, Chlorophyta) from the Florida coast, local aquarium shops, and e-commerce: establishing a proactive baseline for early detection. J. Phycol. 42 1113-1124.

SURVEYMONKEY (2010) URL: http://www.surveymonkey.com/ (Accessed 4 November 2008.

WALTERS LJ, BROWN KR, STAM WT and OLSEN JL (2006) E-Commerce and Caulerpa, unregulated dispersal of invasive species. Front. Ecol. Environ. 4 75-9. 


\section{Appendix 1}

\section{PET STORE QUESTIONNAIRE}

\section{Could you successfully identify? $0=$ No, $5=100 \%$ certain}

Hydrilla verticillata (Hydrilla)

Vallisneria spiralis (Tape Grass )

Lagarosiphon major (South African oxygen weed)

Lagarosiphon muscoides

Egeria densa (Dense water weed)

Potamogeton crispus (Curly pondweed)

Elodea canadensis (Canadian water weed)

Myriophyllum spicatum (Spiked water-milfoil, Eurasian water-milfoil)

Cabomba caroliniana (Fan wort)

Cabomba furcata (Red cabomba)

Ceratophyllum demersum (hornwort)

Echinodorus cordifolius (Spade-leaf sword, radicans sword)

$\begin{array}{llllll}0 & 1 & 2 & 3 & 4 & 5 \\ 0 & 1 & 2 & 3 & 4 & 5 \\ 0 & 1 & 2 & 3 & 4 & 5 \\ 0 & 1 & 2 & 3 & 4 & 5 \\ 0 & 1 & 2 & 3 & 4 & 5 \\ 0 & 1 & 2 & 3 & 4 & 5 \\ 0 & 1 & 2 & 3 & 4 & 5 \\ 0 & 1 & 2 & 3 & 4 & 5 \\ 0 & 1 & 2 & 3 & 4 & 5 \\ 0 & 1 & 2 & 3 & 4 & 5 \\ 0 & 1 & 2 & 3 & 4 & 5 \\ 0 & 1 & 2 & 3 & 4 & 5\end{array}$

\section{Have you ever had the opportunity to acquire this species for your business?}

Hydrilla verticillata (Hydrilla)

Vallisneria spiralis (Tape grass)

Lagarosiphon major (South African oxygen weed)

Lagarosiphon muscoides

Egeria densa (Dense water weed)

Potamogeton crispus (Curly pondweed)

Elodea canadensis (Canadian water weed)

Myriophyllum spicatum (Spiked water-milfoil, Eurasian water-milfoil)

Cabomba caroliniana (Fan wort)

Cabomba furcata (Red cabomba)

Ceratophyllum demersum (hornwort)

Echinodorus cordifolius (Spade-leaf sword, radicans sword)

$\begin{array}{ll}\text { Yes } & \text { No } \\ \text { Yes } & \text { No } \\ \text { Yes } & \text { No } \\ \text { Yes } & \text { No } \\ \text { Yes } & \text { No } \\ \text { Yes } & \text { No } \\ \text { Yes } & \text { No } \\ \text { Yes } & \text { No } \\ \text { Yes } & \text { No } \\ \text { Yes } & \text { No } \\ \text { Yes } & \text { No } \\ \text { Yes } & \text { No }\end{array}$

\section{Do you have this species in stock?}

Hydrilla verticillata (Hydrilla)

Vallisneria spiralis (Tape grass)

Lagarosiphon major (South African oxygen weed)

Lagarosiphon muscoides

Egeria densa (Dense water weed)

Potamogeton crispus (Curly pondweed)

Elodea canadensis (Canadian water weed)

Myriophyllum spicatum (Spiked water-milfoil, Eurasian water-milfoil)

Cabomba caroliniana (Fan wort)

Cabomba furcata (Red cabomba)

Ceratophyllum demersum (hornwort)

Echinodorus cordifolius (Spade-leaf sword, radicans sword)

\section{How do you acquire your aquatic plants?}

Mail order

Delivery from companies

Self collection

Self grown

Other

\section{How do you select the plants you sell?}

Aesthetic value

Availability

Demand

Hardiness

Catalogue

Other 
6. Have you ever imported aquatic plants from abroad?

7. Are you aware of the Conservation of Agricultural Resources Act regarding aquatic plants?

8. Are you aware of the National Environmental Management Amendment Act (NEMBA)?

9. Do you agree with these regulatory measures and any other comments?

10. Optional, where is your business located?

City/Town:

State/Province:

\section{AQUARIST QUESTIONNAIRE}

\section{Could you successfully identify?}

Hydrilla verticillata (Hydrilla)

Vallisneria spiralis (Tape grass )

Lagarosiphon major (African elodea, curly waterweed, oxygen weed, South African oxygen weed )

Lagarosiphon muscoides

Egeria densa (Dense water weed)

Potamogeton crispus (Curly pondweed)

Elodea canadensis (Canadian water weed)

Myriophyllum spicatum (Spiked water-milfoil, Eurasian water-milfoil)

Cabomba caroliniana (Fan wort)

Cabomba furcata (Red cabomba)

Ceratophyllum demersum (hornwort)

Echinodorus cordifolius (Spade-leaf sword, radicans sword)

Yes

Yes

Yes

Yes

Yes

Yes

Yes

Yes

Yes

Yes

Yes

Yes

\section{Is it indigenous and/or invasive}

Hydrilla verticillata (Hydrilla)

Vallisneria spiralis (Tape grass)

Lagarosiphon major (African elodea, curly waterweed, oxygen weed, South African oxygen weed)

Lagarosiphon muscoides

Egeria densa (Dense water weed)

Potamogeton crispus (Curly pondweed)

Elodea canadensis (Canadian water weed)

Myriophyllum spicatum (Spiked water-milfoil, Eurasian water-milfoil)

Cabomba caroliniana (Fan wort)

Cabomba furcata (Red cabomba)

Ceratophyllum demersum (hornwort)

Echinodorus cordifolius (Spade-leaf sword, radicans sword)
Indigenous

Indigenous

Indigenous

Indigenous

Indigenous

Indigenous

Indigenous

Indigenous

Indigenous

Indigenous

Indigenous

Indigenous
Invasive Invasive Invasive Invasive Invasive Invasive Invasive Invasive Invasive Invasive Invasive Invasive

\section{Have you ever had the opportunity to acquire this species?}

Hydrilla verticillata (Hydrilla)

Vallisneria spiralis (Tape grass)

Lagarosiphon major (African elodea, curly waterweed, oxygen weed, South African oxygen weed) Lagarosiphon muscoides

Egeria densa (Dense water weed)

Potamogeton crispus (Curly pondweed)

Elodea canadensis (Canadian water weed)

Myriophyllum spicatum (Spiked water-milfoil, Eurasian water-milfoil)

Cabomba caroliniana (Fan wort)

Cabomba furcata (Red cabomba)

Ceratophyllum demersum (hornwort)

Echinodorus cordifolius (Spade-leaf sword, radicans sword) 


\section{Do you or have you ever had this species in you aquarium/tank?}

Hydrilla verticillata (Hydrilla)

Vallisneria spiralis (Tape grass)

Lagarosiphon major (African elodea, curly waterweed, oxygen weed, South African oxygen weed)

Lagarosiphon muscoides

Egeria densa (Dense water weed)

Potamogeton crispus (Curly pondweed)

Elodea canadensis (Canadian water weed)

Myriophyllum spicatum (Spiked water-milfoil, Eurasian water-milfoil)

Cabomba caroliniana (Fan wort)

Cabomba furcata (Red cabomba)

Ceratophyllum demersum (hornwort)

Echinodorus cordifolius (Spade-leaf sword, radicans sword)

5. Do you or have you ever passed this species on to colleague or friend?

$\begin{array}{lr}\text { Hydrilla verticillata (Hydrilla) } & \text { Yes } \\ \text { Vallisneria spiralis (Tape grass) } & \text { Yes } \\ \text { Lagarosiphon major (African elodea, curly waterweed, oxygen weed, South African oxygen weed) } & \text { Yes } \\ \text { Lagarosiphon muscoides } & \text { No } \\ \text { Egeria densa (Dense water weed) } & \text { Yes } \\ \text { Potamogeton crispus (Curly pondweed) } & \text { Yes } \\ \text { Elodea canadensis (Canadian water weed) } & \text { No } \\ \text { Myriophyllum spicatum (Spiked water-milfoil, Eurasian water-milfoil) } & \text { No } \\ \text { Cabomba caroliniana (Fan wort) } & \text { Yes } \\ \text { Cabomba furcata } \text { (Red cabomba) } & \text { Yes } \\ \text { Ceratophyllum demersum (hornwort) } & \text { No } \\ \text { Echinodorus cordifolius (Spade-leaf sword, radicans sword) } & \text { Yes } \\ \end{array}$

\section{In your opinion does this species pose a threat to our water systems?}

Hydrilla verticillata (Hydrilla)

Vallisneria spiralis (Tape grass)

Lagarosiphon major (African elodea, curly waterweed, oxygen weed, South African oxygen weed)

Elodea canadensis (Canadian water weed)

Myriophyllum spicatum (Spiked water-milfoil, Eurasian water-milfoil)

Cabomba caroliniana (Fan wort)

Cabomba furcata (Red cabomba)

7. Are you aware of the Conservation of Agricultural Resources Act regarding aquatic plants?

8. Are you aware of the National Environmental Management Amendment Act (NEMBA)?

\section{Do you agree with these regulatory measures?}

10. Any other comments regarding aquatic plants and /or their regulation in South Africa 